\title{
Evaluation of Antimicrobial Effect of Propolis, Miswak, Green Tea Compared to Sodium Hypochlorite and Chlorhexidine as Root Canal Irrigants
}

\author{
Abeer M. Darag'1, Dalia M. Fayyad², Abd El Azeem M. El Gammal³, \\ Ashraf A. Soliman ${ }^{*}$ \\ ${ }^{1}$ Department of Endodontics, Faculty of Dentistry, Tanta University, ${ }^{2}$ Department of Endodontics, Faculty of \\ Dentistry, Suez Canal University, Department of Bacteriology, Mycology and Immunology, Faculty of Veteri- \\ nary Medicine, Suez Canal University, Egypt
}

\begin{abstract}
Background: To assess the antibacterial effect of ethanolic extract of propolis, miswak and green tea compared to sodium hypochlorite and chlorhexidine as root canal irrigants against E.faecalis biofilm using laboratory culturing and scanning electron microscope (SEM). Materials and Methods: fifty, human, single canalled teeth were used. The crown of each tooth was sectioned. After root canal preparation and sterilization, the roots were infected with E. faecalis. Roots inoculated with E.faecalis were incubated at $37 \mathrm{Co}$ for 7 days. Then root canals were instrumented using Revo S NiTi files and different irrigants: Sodium hypochlorite 3\% ( $\mathrm{NaOCl}), 2 \%$ chlorhexidine (CHX), 20\% ethanolic extract of Egyptian propolis, 20\% ethanolic extract of Miswak and $20 \%$ ethanolic extract of Green tea. Root canals were sampled before (S1) and immediately after the chemo- mechanical preparation (S2). The data obtained collected, tabulated, and statistically analyzed. Results: $\mathrm{NaOCl}$ group (2.56 2.74$)$ showed the lowest mean Log10 of bacterial counts, it was non-statistically significant different from CHX group (3.83 \pm 2.37$)$, Propolis group (4.62 \pm 1.88$)$ and Miswak group (4.93 \pm 2.01$)$. NaOCl group showed statistically significantly lower mean Log10 of bacterial counts than Green tea group (5.82 \pm 0.16$)$ and Saline group (6.39 \pm 0.30$)$. Conclusion: Propolis, Salvadora Perisca and green tea offer a promising natural antimicrobial alternative and may serve as a new endodontic irrigants.
\end{abstract}

Keywords: E. faecalis, herbal irrigants, root canal disinfectants

\section{Introduction}

The use of irrigating solutions is an important part of effective chemomechanical preparation. It enhances bacterial elimination and facilitates emoval of necrotic tissue and dentine chips from the root canal. Irrigants can prevent packing of the infected hard and soft tissue apically in the root canal and into the periapical area(1). The most popular endodontic irrigant is sodium hypochlorite (Na$\mathrm{OCl}$ ), which has been used for well 
over four decades. Although it is an effective antimicrobial agent and an excellent organic solvent, it is known to be highly irritant to the periapical tissues, mainly at high concentrations. For this reason the search for another irrigant with a lower potential to induce adverse effects is desirable ${ }^{(2)}$. Chlorhexidine gluconate (CHX) has also been recommended as a root canal irrigant and many studies have demonstrated its broad spectrum antimicrobial action, substantivity, and low grade of toxicity. However the inability of chlorhexidine to dissolve pulp tissue has been a problem, some attempts were made to solve this deficiency by the combined use of $\mathrm{NaOCl}$ and $\mathrm{CHX}^{(3)}$. Propolis is a natural non-toxic beehive product, which is used for building and restoration of the honey comb. In the hive, propolis act as a biocide, being active against the invasive bacteria, fungi and even invading larvae. Other biological activities have also been depicted for propolis, including antibacterial, antifungal, antiviral, antitumor, immunemodulation. Anti-bacterial activity of propolis ethanolic extract of different geographic origin against oral pathogens has been studied by several authors ${ }^{(4)}$. Miswak is mainly used to describe the stick, which is used for cleansing the teeth. Arak is the plant from which Miswak is derived (Salvadora persica). Many studies have been carried out on different types of chewing sticks focused mainly on antimicrobial activity of these sticks(5). Green tea is a non-fermented tea, and contains more Catechins, than black tea or oolong tea. Catechins are strong anti-oxidants. In addition, its content of certain minerals and vitamins increases the antioxidant potential of this type of tea. Green tea has been consumed throughout the ages in India, China, Japan and Thailand. Recent human studies suggested that green tea contributes to overall oral health. It has been used in dentistry and has a promising role in future ${ }^{(6)}$.

\section{Materials and Methods}

Fifty freshly extracted, human, permanent single canalled teeth were collected. The crown of each tooth was sectioned with a diamond disc to standardize the length of samples at $17 \mathrm{~mm}$. Initial preparation of root canals was carried out serially to master apical file size $30 \mathrm{~K}$-files. Coronal flaring was done using number 2 and 3 Gates Glidden burs. All specimens were inserted inside sterilization pack and autoclaved for 20 minutes at $121 C^{\circ}$. Isolated colonies of E. faecalis were scraped, aseptically suspended in brain heart infusion broth, using a sterile micropipette, $20 \mu \mathrm{l}$ of the bacterial suspension was syringed into each root canal until the entire canal space was filled with fluid. Roots inoculated with $E$. faecalis were incubated at $37 \mathrm{C}^{\circ}$ for 7 days. After 7 days of experimental contamination, two roo-ts were longitudinally split, subjected to scanning electron microscope (SEM) examination to confirm biofilm structure. Forty-eight roots were randomly classified into six experimental groups $(n=8)$ according to the type of antimicrobial irrigant solutions: Group 1: treated with: Sodium hypochlorite 3\% ( $\mathrm{NaOCl})$, Group 2: treated with: $2 \%$ chlorhexidine ( $\mathrm{CHX}$ ), Group 3: treated with: $20 \%$ ethanolic extract of Egyptian propolis, Group 4: treated with: $20 \%$ ethanolic extract of Miswak, Group 5: treated with: 20\% ethanolic extract of Green tea, Group 6: treated with: Saline (control). In all 
groups, root canals were instrumented using rotary Revo $\mathrm{S}$ NiTi files with crown down technique. After the use of each file, $3 \mathrm{ml}$ of the irrigant according to its group was injected into the root canal for a total of $30 \mathrm{ml}$ irrigation in each root canal. Root canals were sampled before (S1) and immediately after the chemo- mechanical preparation (S2). Root canals were filled with sterile saline and the samples were taken by three dry sterile paper points placed to the full WL kept in the canal for 1 min then transferred to tubes containing $.05 \mathrm{~mL} \mathrm{BHI}$ broth solution. After obtaining 1:10 serial dilution from each sample, aliquots were plated out on KF streptococcus agar plates and spread using sterile platinum loop. Then the plates were incubated anaerobically at $37 \mathrm{C}$ for 2 days. The number of bacterial colonies of $E$. faecalis were counted and expressed as CFUs using a digital colony counter. The data obtained collected, tabulated, and statistically analyzed.

\section{Results}

Before chemomechanical preparation, there was no statistically significant difference between the groups. While after preparation; there was a statistically significant difference. Although $\mathrm{NaOCl}$ group $(2.56 \pm 2.74)$ showed the lowest mean $\log _{10}$ of bacterial counts, it was non-statistically significant different from $\mathrm{CHX}$ group (3.83 \pm 2.37$)$, Propolis group $(4.62 \pm 1.88)$ and Miswak group (4.93 \pm 2.01). $\mathrm{NaOCl}$ group showed statistically significantly lower mean $\log _{10}$ of bacterial counts than Green tea group $(5.82 \pm 0.16)$ and Saline group (6.39 \pm 0.30). Saline group showed the highest mean $\log _{10}$ of bacterial counts $(6.39 \pm 0.30)$. It showed statistically significant difference from all groups except Green tea group.

Table 1: Mean $\log _{10}$, standard deviation (SD) values and results of comparison between $\log _{10} \mathrm{CFU}$ of bacterial counts before and after preparation within each group (In vitro study)

\begin{tabular}{|l|c|c|c|c|c|}
\hline \multirow{2}{*}{} & \multicolumn{2}{|c|}{$\begin{array}{c}\text { Before } \\
\text { preparation }\end{array}$} & \multicolumn{2}{c|}{$\begin{array}{c}\text { After } \\
\text { preparation }\end{array}$} & \multirow{2}{*}{ P-value } \\
\cline { 2 - 5 } & $\begin{array}{c}\text { Mean } \\
\log _{10}\end{array}$ & SD & $\begin{array}{c}\text { Mean } \\
\text { Log }_{10}\end{array}$ & SD & \\
\hline $\mathrm{NaOCl}$ & 7.21 & 0.08 & 2.56 & 2.14 & $0.012^{*}$ \\
\hline $\mathrm{CHX}$ & 7.15 & 0.16 & 3.83 & 2.37 & $0.012^{*}$ \\
\hline Propolis & 7.08 & 0.18 & 4.62 & 1.88 & $0.012^{*}$ \\
\hline Miswak & 7.16 & 0.18 & 4.93 & 2.01 & $0.012^{*}$ \\
\hline Green tea & 7.19 & 0.16 & 5.82 & 0.16 & $0.012^{*}$ \\
\hline Saline & 7.02 & 0.44 & 6.39 & 0.30 & $0.012^{*}$ \\
\hline
\end{tabular}

*: Significant at $P \leq 0.05$

\section{Discussion}

Results of this invitro part indicated that the most effective root canal irrigant for disrupting biofilms and achieving a negative culture was $3 \%$
$\mathrm{NaOCl}$ followed by $2 \% \mathrm{CHX}$ which effectively reduced the CFU (CHX group results showed non-statistically significant difference from $\mathrm{NaOCl}$ group (99.39 \pm 0.44$)$. This agreed with many studies; Giardino et al.(7) showed that 
$5.25 \% \mathrm{NaOCl}$ could disintegrate and remove the $E$ faecalis biofilm generated on cellulose nitrate membrane filters at all tested times starting from 5 minutes up to 60 minutes. Dunavant et $a^{(8)}$ revealed that $6 \% \mathrm{NaOCl}$ was able to eliminate the $E$. faecalis biofilm after 1 and 5 minutes. Whereas, 2\% $\mathrm{CHX}$ was less effective; achieving $60.5 \%$ kill. Moreover, Clegg et al(9) reported that $6 \% \mathrm{NaOCl}$ applied for
$15 \mathrm{~min}$ was capable of rendering bacteria non-viable and physically removing the polymicrobial biofilm generated on hemisections of root apices. They also reported that $2 \% \mathrm{CHX}$ applied for the same time duration resulted in negative cultures from the specimens, but failed to disrupt the biofilm completely as revealed by SEM examination.

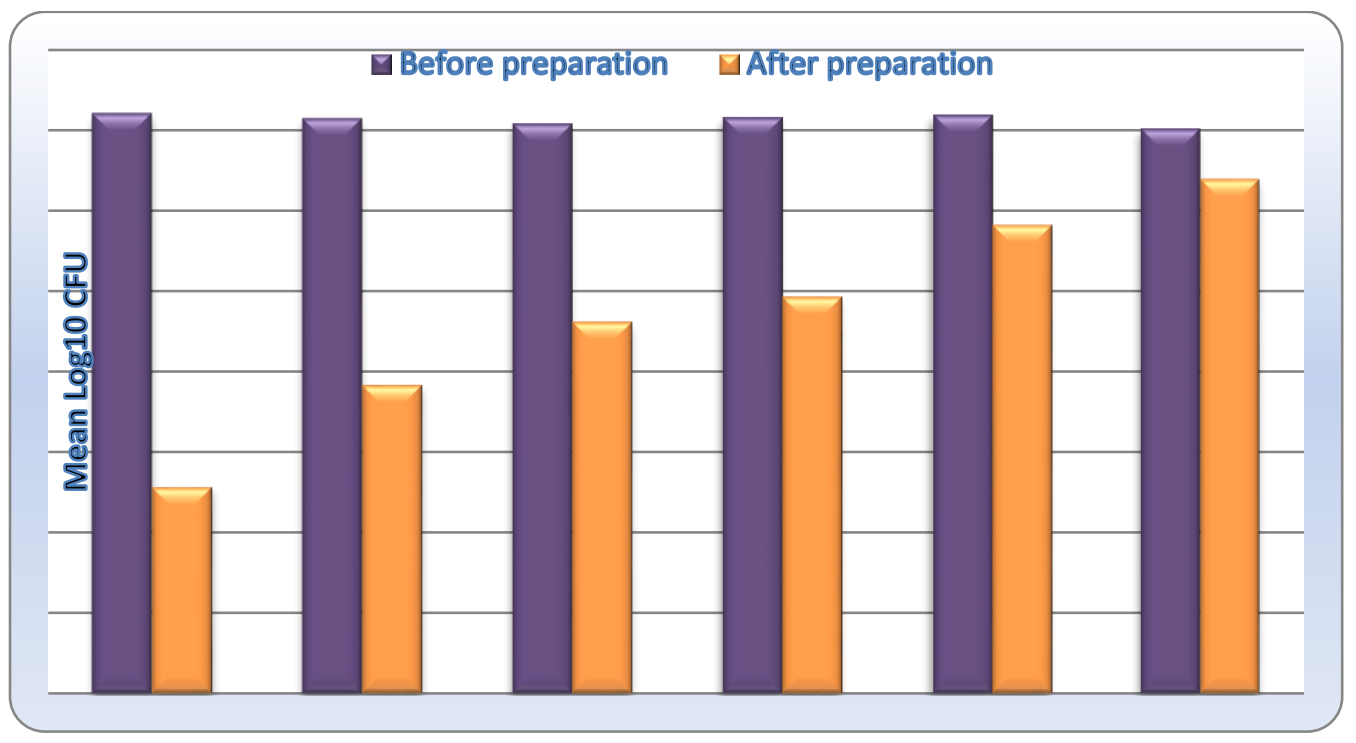

Figure 1: Bar chart representing changes after preparation in mean $\log _{10}$ CFU of bacterial counts (in vitro study)

Also, Abdullah et $\mathrm{al}^{(10)}$ found that $E$. faecalis grown in biofilm to be more resistant to $0.2 \% \mathrm{CHX}$ than to $3 \% \mathrm{Na}$ $\mathrm{OCl}$; where the latter achieved a 100\% kill in 2 minutes time. Similarly, Spratt et $\mathrm{al}^{(11)}$ showed that $2.25 \% \mathrm{NaOCl}$ achieved a $100 \%$ kill of $E$. faecalis grown on cellulose nitrate membrane filters after 15 minutes while $0.2 \% \mathrm{CHX}$ was effective after 60 minutes. Furthermore, Senia et $\mathrm{al}^{(12)}$ revealed that $5.25 \% \mathrm{NaOCl}$, with and without mechanical agitation, eliminated single species biofilm of E. faecalis in $30 \mathrm{sec}-$ onds. They also revealed that $2 \% \mathrm{CHX}$, with agitation, eradicated both organisms in 30 seconds' time. Such great efficiency in eliminating intracanal microorganisms of $\mathrm{NaOCl}$ might be due to hypochlorite acid which is a powerful oxidizing agent that produces an antimicrobial effect by irreversible oxidetion of hydrosulphuric groups of bacterial enzymes. As essential enzymes are inhibited, disturbing the metabolic functions of the bacterial cell occurred resulting in the death of bacterial cells. Chlorine can also adhere to bacterial cytoplasm components forming highly toxic $\mathrm{N}$-chloro 
composites that destroy the microorganisms. The SEM observation after $3 \% \mathrm{NaOCl}$ irrigation confirmed the negative culture results, which was in accordance with Clegg et al ${ }^{(9)}$ The antimicrobial effectiveness of $\mathrm{NaOCl}$ might also be attributed to its tissue dissolving capacity and therefore it may be less inhibited by the extracellular matrix of the biofilm. Consequently, the removal of the organic tissue eliminates the bacterial attachment to the surface and to other microorganisms. SEM images after $2 \%$ $\mathrm{CHX}$ irrigation showed residual bacteria and exopolymeric material persisting on the dentine surface. This was in consistence with findings of Clegg et al(9), who noted a virtually intact biofilm after exposure to $\mathrm{CHX}$. CHX has consistently been found less effective than $\mathrm{NaOCl}$ in biofilm studies ${ }^{(10)}$. On the other hand, these results were not consistent with Önçag et $a^{(13)}$, who tested $\mathrm{CHX}$ on root segments infected with $E$. faecalis. They concluded that $\mathrm{CHX}$, whether alone, in a concentration of $2 \%, 0.2 \%$ or combined with cetrimide, was more effective than $\mathrm{NaOCl}$. The difference could be attributed to the residual antibacterial effect of CHX. Önçag et al(13) evaluated the antibacterial efficacy after $48 \mathrm{~h}$ and 2 weeks in their model, whereas in our study the antibacterial efficacy was evaluated immediately after chemo mechanical preparation. Our study showed that the antimicrobial activity of $20 \%$ propolis ethanolic extract was less effective than $\mathrm{NaOCl}$ and $\mathrm{CHX}$ against E. faecalis; however, there was non-statistically significant difference between $\mathrm{NaOCl}, \mathrm{CHX}$ and propolis. This was in agreement with many studies; Bruschi et $\mathrm{al}^{(14)}$, who reported good antimicrobial activity of propolis against E. faecalis' Nara et $\mathrm{al}^{(15)}$, concluded that propolis has good antimicrobial activity however this activity was much lower than $\mathrm{NaOCl}$ Also, Awawdeh et $\mathrm{al}^{(16)}$ concluded that propolis is very effective as intracanal medicament in rapidly eliminating E. faecalis Moreover, AlQathmi and Al-Madi(17) found that propolis was as effective as $\mathrm{NaOCl}$ when used as an antimicrobial irrigant on extracted human teeth. Recent studies done by Kandaswamy et $\mathrm{al}^{(18)}$ and Kayaoglu et $\mathrm{al}^{(19)}$ concluded that the antimicrobial activity of the propolis against $\mathrm{E}$. faecalis was between $\mathrm{Ca}$ $(\mathrm{OH})_{2}$ and $\mathrm{CHX}$. However, this activity did not exceed $\mathrm{CHX}$. One hypothesis is that previous studies used an ethanol extract of propolis and this extraction process may free up more of the active antimicrobial components of propolis such as the flavonoids and flavonones. Macedo et $\mathrm{al}^{(20)}$ stated, "Several herbal, animal and microbial extracts possess quorum-quenching activity but few active compounds and synthetic analogues are known. It is possible that through the extraction process the compound availability is altered to enhance the antimicrobial effect Bulman et al $^{(21)}$ found propolis to contain compounds that suppress the quorum-sensing response. Our study may be exemplifying this anti- quorum sensing effect. By interfering with quorum sensing, it may be disallowing bacteria to aggregate in a structural and functional manner that is necessary for them to thrive as a biofilm. This could be one of the mechanisms by which the antimicrobial extracts of propolis function. Quite the contrary, the study done by Gupta et $\mathrm{al}^{(22)}$ showed that $30 \%$ propolis extract was not effective against E. faecalis One factor that 
could be responsible for this ineffectiveness of the propolis solutions is their low $\mathrm{pH}$ values. The $\mathrm{pH}$ for $30 \%$ propolis in Dimethyl sulfoxide was determined to be 4.9-5.2, whereas it was 3.8-4.2 for the Ethyl alcohol solution. Mchugh et $\mathrm{al}^{(23)}$ found that $\mathrm{pH}$ 10.5-11.0 retarded the growth of $E$. faecalis, whereas at $\mathrm{pH} 11.5$ or greater, E. faecalis was destroyed. Comparisons of the antimicrobial effect between $3 \% \mathrm{NaOCl}, 2 \% \mathrm{CHX}$ and $20 \% \mathrm{Sal}-$ vadora Perisca showed that all were effective against $E$. faecalis expressed by significant reduction in mean bacterial count. However, the antibacterial activity of $20 \%$ Salvadora Perisca was the least. These findings come in accordance with previous studies $^{(24,25)}$.

\section{Conclusion}

We conclude that: 1 - The biofilm model is effective in determining the in vitro antimicrobial efficacy of different root canal irrigants. 2-The effectiveness of $\mathrm{NaOCl}$ and $\mathrm{CHX}$ are confirmed and proved to be able to remove the biofilm organized on the root canal walls. 3-Propolis, Salvadora Perisca and green tea alcoholic extracts at $20 \%$ concentration show considerable antimicrobial effect against chronic apical periodontitis microbes generally and E. faecalis definitely. Thus, Propolis, Salvadora Perisca and green tea offer a promising natural antimicrobial alternative and may serve as a new endodontic irrigants.

\section{References}

1. Siqueira JF Jr, Rocas IN, Favieri A, Lima KC. Chemomechanical reduction of the bacterial population in the root canal after instrumentation and irrigation with $1 \%, 2.5 \%$, and
$5.25 \%$ sodium hypochlorite. J Endod 2000; 26(6):331-4.

2. Estrela C, Estrela CR, Barbin EL, Spanó JC, Marchesan MA, Pécora JD. Mechanism of action of sodium hypochlorite. Braz Dent J 2002; 13 (2):113-7.

3. Vianna $M E$, Gomes $B P$, Berber $V B$, Zaia AA, Ferraz CC, de Souza- Filho FJ. In vitro evaluation of the antimicrobial activity of chlorhexidine and sodium hypochlorite. Oral Surg Oral Med Oral Pathol Oral Radiol Endod 2004; 97(1): 79-84.

4. Ehsani M, Amin Marashi MA, Zabihi E, Issazadeh $M$, Khafri S. A comparison between anti-bacterial activity of propolis and aloe vera on enterococcus faecalis (an invitro study). Int J Mol Cell Med 2013; 2 (3):44-59.

5. Al-Salman TH, Al-Shaekh Ali MG, AlNu'aimy $\mathrm{OM}$. The antimicrobial effect of water extraction of Salvadora persica (Miswak) as a root canal irrigant. Al-Rafidain Dental Journal. 2005; 5:33-36.

6. Horiba $\mathrm{N}$, Maekawa $\mathrm{Y}$, Ito $\mathrm{M}$, Matsumoto T, Nakamura H. A pilot study of Japanese green tea as a medicament: Antibacterial and bactericidal effects. J Endod 1991; 17(3):122-24.

7. Giardino L, Savoldi E, Ambu E, Rimondini R, Palezona A, Debbia EA. Antimicrobial effect of MTAD, Tetraclean, Cloreximide, and sodium hypochorite on three common endodontic pathogens. Indian J Dent Res 2009; 20 (3): -391.

8. Dunavant TR, Regan JD, Glickman GN, Solomon ES, Honeyman AL. Comparative evaluation of endodontic irrigants against Enterococcus faecalis biofilms. J Endod 2006; 32(6):527-31.

9. Clegg MS, Vertucci FJ, Walker C, Belanger $M$, Britto LR.The effect of exposure to irrigant solutions on apical dentin biofilms in vitro. J Endod 2006; 32(5): 434-7. 
10. Abdullah $\mathrm{M}, \mathrm{Ng} \mathrm{YL}$, Gulabivala K, Moles DR, Spratt DA. Susceptibilties of two Enterococcus faecalis phenotypes to root canal medications. J Endod 2005; 31(1): 30-6.

11. Spratt DA, Pratten J, Wilson M Gulabivala $\mathrm{K}$. An in vitro evaluation of antimicrobial efficacy of irrigants on biofilms of root canal isolates. Int Endod J 2001; 34(4) :300-7.

12. Senia SE, Marshall JF, Rosen S. The solvent action of sodium hypochlorite on pulp tissue of extracted teeth. Oral Surg, Oral Med, Oral Path 1970; 31(1):96-103.

13. Oncag O, Cogulu D, Uzel A, Sorkun K. Evaluation of in vitro antimicrobial activity of various propolis samples against enterococcus faecalis. Balkan Journal of Stomatology 2006; 10 (2):33-42.

14. Bruschi $\mathrm{ML}$, Lara $\mathrm{EH}$, Martins $\mathrm{CH}$, et al. Preparation and antimicrobial activity of gelatin microparticles containing propolis against oral pathogens. Drug Dev Ind Pharm 2006; 32(2): 229-38.

15. Nara A, Dhanu, Chandra P, Anandakrishna L, Dhananjaya. Comparative evaluation of antimicrobial efficacy of MTAD, $3 \% \mathrm{NaOCl}$ and propolis against $E$. faecalis. Int $J$ Clin Pediatr Dent. 2010;3(1):21-5.

16. Awawdeh L, AL-Beitawi M, Hammad M. Effectiveness of propolis and calcium hydroxide as a shortterm intracanal medicament against Enterococcus faecalis: A laboratory study. Aust Endod J 2009; 35(2):52-8.

17. Al-Qathami H, Al-Madi E. Comparison of sodium hypochlorite, propolis and saline as root canal irrigants: A pilot study. Saudi Dent J 2003; 15 (2):100-103.

18. Kandaswamy D, Venkateshbabu N, Gogulnath D, Kindo AJ. Dentinal tubule disinfection with $2 \%$ chlorhexidine gel, propolis, morinda citrifolia juice, $2 \%$ povidone iodine, and calcium hydroxide. Int Endod J 2010; 43 (5):419-23.

19. Kayaoglu G, Ömürlü H, Akca $G$, et al. Antibacterial activity of propolis versus conventional endodontic disinfectants against Enterococcus faecalis in infected dentinal tubules. J Endod 2011; 37 (3):376-81.

20. Macedo AF, Marques FB, Ribeiro CF, Teixeira F. Causality assessment of adverse drug reactions: comparison of the results obtained from published decisional algorithms and from the evaluations of an expert panel, according to different levels of imputability. J Clin Pharm Ther 2003; 28 (2):137-43.

21. Bulman Z, Le P, Hudson AO, Savka MA. A novel property of propolis (bee glue): anti-pathogenic activity by inhibition of $\mathrm{N}$-acyl-homoserine lactone mediated signaling in bacteria. J Ethnopharmacol 2011; 138 (3):788-97.

22. Gupta S, Kundabala M, Acharya S and Ballal V. A comparative evaluation of antibacterial efficacy of propolis, $3 \%$ sodium hypochlorite and $2 \%$ chlorhexidine gluconate against E. faecalis ; An invitro study. Endodontology 2007; 19:31-38.

23. McHugh $C P$, Zhang $P$, Michaelek $S$ ,Eleazer PD. pH required to kill Enterococcus faecalis in vitro. J Endod 2004; 30 (4):218-9.

24. Ayhan $H$, Sultan $N$, Cirak $M$, Ruhi $M Z$, Bodur $H$. Antimicrobial effects of various endodontic irrigants on selected microorganisms. Int Endod J 1999; 32 (2):99-102.

25. AL-Bagieh NH, Idowu A, Salako N. The effect of aqueous extract of miswak on the in vitro growth of Candida albicans. Microcios 1994; 80 (323):107- 13 
